Vol.05, No.01, April 2019

Doi: $10.24198 /$ cosmogov.v2i2.xxxxx

\title{
COPRODUCTION SEBAGAI SOLUSI ATAS PEMBARUAN LAYANAN OLEH WARGA (CITIZEN WELFARE) KAMPUNG WISATA 3G (GLINTUNG GO GREEN)
}

\author{
Bramantyo Tri Asmoro ${ }^{1}$ \\ Muhamad Imron ${ }^{2}$ \\ ${ }^{1}$ Program Studi Ilmu Pemerintahan Universitas Islam Raden Rahmat Malang \\ ${ }^{2}$ Program Studi Ilmu Pemerintahan Universitas Islam Raden Rahmat Malang
}

Email: bramtriasmoro@gmail.com

\begin{abstract}
ABSTRAK
Tren pengembangan desa wisata akhir-akhir ini tengah menjamur di seluruh pelosok Indonesia. Keindahan dan keunikan yang dimiliki oleh desa-desa di Indonesia menyimpan banyak potensi yang dapat dikembangkan agar menjadi sebuah kawasan yang tidak hanya berfungsi sebagai hunian, namun juga berfungsi sebagai kekuatan ekonomi bagi masyarakat lokal setempat. Terkait dengan potensi yang dimiliki desa, dibutuhkan kerjasama antara masyarakat dan pemerintah untuk mendesain format dari desa wisata itu sendiri. Beberapa desa ada yang menonjolkan sisi keunggulan alam, beberapa ada yang lebih menunjukkan sisi keunikan budaya. Dalam era citizen welfare, warga negara mempunyai peran yang lebih besar dalam pembangunan. Peran pemerintah dalam membangun desa wisata bergeser menjadi partner masyarakat, dengan melakukan fungsi empowerment dan enabling, salah satunya melalui model kerjasama coproduction yang dapat meningkatkan nilai tambah desa wisata.
\end{abstract}

Kata Kunci: desa wisata; citizen welfare; model coproduction

\begin{abstract}
The development of tourism village has becoming trends in Indonesia. The beauty and uniqueness of villages in Indonesia holds a lot of potential that can be developed to become an area that not only functions as a residence, but also serves as an economic force for local communities. Regarding the potential of the village, cooperation between the community and the government is needed to design the format of the tourism village itself. Some village highlighted the beauty of nature, some of which are more of the uniqueness of local culture. In the era of citizen welfare, citizens have a greater role in development. The role of the government in developing tourism villages shifts to become community partners, by carrying out empowerment and enabling functions, one of which is through a coproduction collaboration model that can increase the added value of tourism villages.
\end{abstract}

Keywords: tourism village; citizen welfare; coproduction model 
Vol.05, No.01, April 2019

Doi: $10.24198 / \operatorname{cosmogov.v2i2.xxxxx}$

\section{PENDAHULUAN}

Sebagian besar desa wisata terletak di wilayah pedesaan, namun seiring dengan semakin meningkatnya daya kreatifitas masyarakat desa, kini desa wisata tidak hanya dikembangkan di wilayah pedesaan saja, tapi juga semakin banyak muncul desa-desa wisata di perkotaan. Situasi perkotaan yang semakin padat, penuh dengan polusi, menginspirasi masyarakatnya untuk banyak berkreasi agar situasi dan persoalan yang tengah dihadapi (padatnya penduduk dan polusi udara) dapat mereka minimalisir. Hal tersebut menjadi salah satu tujuan masyarakat di perkotaan dalam mengembangkan desa wisata yang mengambil tema penghijauan. Bagaimana pun, bagi masyarakat perkotaan suasana hijau (desa ataupun kampung yang penuh dengan ragam tanaman) merupakan hal yang dirindukan oleh mereka. Romantisme masa lalu yang pernah mereka rasakan saat perkotaan belum sepadat sekarang seolah-olah hadir kembali ditengah-tengah mereka.

Sisi keunikan seperti ini nyatanya juga banyak mengundang masyarakat lain untuk datang dan menikmati keunikan yang disajikan. Inspirasi untuk berkreasi tidak jarang muncul dari arahan pemerintah daerah. Beberapa pemerintah daerah, dengan mempertimbangakan beragam potensi yang dimiliki daerahnya, sengaja membuat berbagai program desa wisata dengan menggelontorkan dana yang tidak sedikit. Desa yang awal mulanya tidak terlalu nampak potensi wisatanya disulap sedemikian rupa menjadi sebuah desa wisata yang menarik untuk dikunjungi. Posisi masyarakat hanya sebagai pelaksana atas ide-ide yang lahir dari para pembuat kebijakan. Tidak jarang pula inisiasi untuk mengembangkan desa wisata tersebut muncul dari masyarakat desa setempat.

Masyarakat desa memiliki ide dan gagasan dan mereka kembangkan dengan basis dan nilai swadaya yang mereka miliki sendiri, hingga menghasilkan sebuah format desa wisata dengan inisiatif masyarakat lokal. Jika pada format desa wisata yang dikembangkan oleh pemerintah, daerah mendapatkan suntikan dana yang besar untuk pengembangan, infrastruktur, hingga pelayanan, maka pada format desa wisata yang berangkat dari inisiasi masyarakat setempat lebih mendahulukan swadaya dan gotong royong. Kelengkapan infrastruktur hingga pelayanan bagi wisatawan dikembangkan sendiri oleh komunitas atau masyarakat setempat tersebut, terkadang nyaris tanpa bantuan dari pemerintah daerah. Meski seringkali saat sebuah desa wisata telah berkembang dengan baik, akhirnya pihak pemerintah daerah juga hadir untuk memberikan beberapa bantuan.

Desa atau kampung wisata yang baik, setidaknya harus memiliki fasilitas yang memadai, infrastruktur yang mendukung, keramahtamahan masyarakat, hingga pada praktek pelayanan yang baik oleh masyarakat. Praktek pelayanan kepada wisatawan oleh masyarakat ini menjadi nilai yang 
Vol.05, No.01, April 2019

Doi: $10.24198 /$ cosmogov.v2i2.xxxxx

akan tampak lebih menarik dari pada praktek layananan yang disediakan oleh pihak pemerintah. Demikian karena seringkali praktek layanan yang dikembangkan oleh masyarakat atau komunitas setempat lebih dapat mengeksplor potensi unik dari desa atau kampung wisata tersebut.

Desa atau kampung wisata $3 \mathrm{G}$ (Glintung Go Green) yang berada di kelurahan Purwantoro, Kota Malang, tengah hangat dibicarakan karena dianggap memiliki keunikan yang luar biasa dengan konsep kampung hijaunya. Kampung hijau ini lahir atas inisiatif warga setempat sejak tiga tahun yang lalu. Selain menyediakan wahana wisata, warga setempat juga mengembangkan inovasi berupa penyediaan layanan bagi para wisatawan yang mengunjungi desa tersebut. Adapun layanan yang dihadirkan atas inisiatif warga desa tersebut berupa layanan menginap (homestay) di rumah-rumah warga, layanan Edu-Green bagi para pengunjung dan peneliti, layanan ojek keliling kampung, hingga layanan pembinaan untuk duplikasi kampung wisata.

Praktek pelayanan oleh masyarakat pada desa wisata $3 \mathrm{G}$ ini begitu menarik untuk dikaji, mengingat inisiasi layanan murni dihasilkan oleh warga setempat. Pemerintah daerah melalui dinas pertanian, dinas kebersihan dan pertamanan juga hadir memberikan berbagai penyuluhan kepada warga setempat. Namun bagi warga, bantuan yang mengalir dari pemerintah daerah baik itu berupa program-program penyuluhan dan kucuran dana, dianggap hanya sebagai stimulan saja. Faktor swadaya dan gotong royong tetap menjadi prioritas utama dalam mengembangkan desa atau kampung wisata Glintung Go Green tersebut.

\section{DASAR PEMIKIRAN}

Pada abad 21 ini, banyak hal-hal besar yang telah mengalami perubahan. Saat dulu segala hal yang berkaitan dengan negara begitu berciri khas sentralistik, kini telah terdesentralisasi. Saat dulu negara begitu aktif memberikan beragam bantuan (pelayanan) melalui institusi-institusi yang ada, kini mengedepankan kemandirian (self help) dari warganya. Selain itu, warga/masyarakat partisipatif, suatu masyarakat yang aktif berperan dalam segala lini pembangunan juga telah menjadi ciri dan tanda khas majunya sebuah negara. Setidaknya beberapa hal diatas telah diutarakan oleh Naisbitt (1982). Berbagai perubahan yang telah terjadi diatas harus direspon dengan baik oleh negara. Menurut Naisbitt, organisasi di era modern harus mampu merespon beragam perubahan besar dengan berbagai cara, diantaranya (Naisbitt, 1982) :

$\checkmark$ Bentuk dan struktur organisasi alternatif berkembang ke arah yang memungkinkan individuindividu yang otonom bekerja dalam kegiatan yang bersifat kolaboratif. 
Vol.05, No.01, April 2019

Doi: $10.24198 /$ cosmogov.v2i2.xxxxx

$\checkmark$ Mengarah ke era desentralisasi dan emansipasi, yang menuntut organisasi dengan model baru yang dapat menampung kontribusi dari individuindividu yang otonom.

$\checkmark$ Perubahan ke arah organisasi yang lebih kecil, otonom dan terfragmentasi, tidak lagi didasarkan pada hirarki tetapi pada jejaring yang bersifat kolaboratif dan fleksibel.

Segala bentuk organisasi kini dituntut untuk mentransformasikan diri dengan berbagai strategi baru yang lebih jitu, seperti strategi kolaboratifkompetitif. Beberapa hal yang disampaikan Naisbitt relevan dengan perkembangan saat ini, dimana individu-individu kian memperoleh otonominya. Saat desentralisasi dan emansipasi kian tak terbendung, maka strategi kolaborasi-kompetitif antar stakeholder tidak bisa dihindarkan lagi. Kolaborasi-kolaborasi yang terjadi ini bisa saja melibatkan organisasiorganisasi kecil yang tidak lagi didasarkan pada hirarki, tetapi lebih pada kekuatan jejaring yang luas dan bersifat kolaboratif serta fleksibel.

\section{Pergeseran dari Corporate Welfare ke Citizen/Community Welfare}

Saat era New Public Management (NPM) berlangsung, peran corporate (korporasi) dalam memberikan pelayanan kepada publik begitu terasa. Negara terkesan menarik diri dan memberikan beberapa pekerjaannya kepada sektor swasta agar dapat mereka kerjakan dengan lebih baik (dari yang telah dikerjakan oleh negara). Beberapa hal yang dinilai mungkin akan lebih baik jika dikelola oleh sektor swasta, maka negara diharapkan memberikan pekerjaan itu kepada swasta (korporasi). Saat privatisasi misalnya dianggap sebagai pilihan tepat, maka negara juga harus melakukannya, dengan alasan agar pelayanan kepada masyarakat yang dihasilkan dari sebuah perusahaan dapat lebih baik lagi. Privatisasi merupakan pilihan tepat guna meningkatkan kualitas layanan pada masyarakat. Negara hanya mengurus sektor-sektor atau unit-unit layanan yang dianggap menyangkut hajat hidup masyarakat, dengan kecenderungan nilai ekonominya yang tidak begitu dominan.

Lambat laun, era corporate welfare kini mulai tergeser oleh pelayanan dengan berbasis partisipasi warga (citizen / community welfare). King dan Stivers (1998) menyatakan bahwa para administrator harus melihat warga negara sebagai warga negara, bukan hanya sekedar pemilih ataupun pelanggan. Mereka perlu membagi kewenangan dan mengurangi kontrol dan percaya pada kemanfaatan dari kolaborasi. Citizen / community welfare mewajibkan pemerintah untuk hadir dalam memastikan atau menjamin bahwa warga negara dapat membuat pilihan-pilihan yang cocok dengan diri mereka dan kepentingan komunitas yang ada dengan menjamin kepastian prosedur dan hak-hak individu. Pada era citizen/community, semangat 
Vol.05, No.01, April 2019

Doi: $10.24198 /$ cosmogov.v2i2.xxxxx

demokrasi memiliki keuntungan yang besar bagi masyarakat. Warga negara diberikan kesempatan yang luas untuk mengembangkan potensi dirinya dan memberikan layanan untuk publik secara luas, pada saat yang sama negara hanya perlu memposisikan diri sebagai penjamin kepastian aturan atas layanan yang dibuat oleh warga negara (citizen) tadi.

\section{Menimbang Peran Pemerintah dalam Tata Kelola Layanan}

Peran pemerintah begitu menarik untuk diperbincangkan terutama pada era citizen/community welfare, saat porsi yang cukup besar telah diberikan kepada warga negara sebagai pemberi layanan dalam masyarakat dan pemerintah dapat melakukan empowering terhadap masyarakat. Pelaksanakan empowering dapat dilakukan oleh pemerintah dengan melakukan penguatan melalui transfer pengetahuan, kemampuan dan ketrampilan. Selain itu, pemerintah juga dapat memberikan posisi, peran, wewenang, lisensi (perijinan) dan emansipasi kepada warga negara. Selain peran empowering, pemerintah menurut Leach, Stewart dan Walsh (1994) juga dapat berperan sebagai enabling, berupa peran indirect service dengan mendorong dan meningkatkan kemampuan-kemampuan yang telah dimiliki oleh warga negara sehingga mereka dapat memenuhi kebutuhan layanan mereka sendiri (community oriented enabler) (Leach, Stewart, Walsh, 1994).
Peran pemerintah berikutnya juga dapat sebagai pengatur (arranger). Wujudnya berupa mengatur atau membuat semacam regulasi tertentu yang memberikan fasilitas bagi berkembangnya peran dan fungsi aktoraktor non publik dalam menyediakan layanan (Savas, 2000). Selain sebagai pengatur, pemerintah juga dapat mengambil peran sebagai partner yakni bekerjasama dalam produksi layanan (cooperation and cooproduction). Sebagai partner, pemerintah dapat melakukan kerjasama yang baik dengan warga negara atau komunitas tertentu yang memberikan layanan kepada masyarakat lainnya. Adapun peran terakhir yang dapat diimplementasikan oleh pemerintah adalah menciptakan sistem demokrasi dan memastikan bahwa individu warga negara berfungsi dalam perwujudan demokrasi tersebut. (Denhardt and Denhardt, 2003).

\section{Tata Kelola Citizen / Community Welfare Service}

Model tata kelola layanan oleh warga negara atau komunitas bisa bermacam-macam bentuknya. Adapun secara lebih rinci dapat kita bagi sebagai berikut:

$\checkmark$ Coproduction, proses produksi dan distribusi barang dan jasa oleh individu yang bukan berasal dari organisasi yang sama. Keterlibatan warga dalam memproduksi layanan yang seharusnya dilakukan oleh pemerintah adalah termasuk kegiatan coproduction dalam 
Vol.05, No.01, April 2019

Doi: $10.24198 /$ cosmogov.v2i2.xxxxx

pelayanan umum (Ostrom: 1996:86). Coproduction adalah proses pemberian layanan baik, dimana pemerintah dan masyarakat membagi tanggung jawab (cojoint responsibility).

$\checkmark$ Contract, pemerintah membuat dan menetapkan kebijakan, pihak swasta menyediakan layanan, sementara masyarakat berperan sebagai konsumen saja (Savas, 2000).

$\checkmark$ Franchise, menurut Savas, pemerintah memberikan hak monopoli kepada suatu perusahaan swasta untuk memberikan pelayanan dalam suatu batas geografis tertentu, dan pemerintah menentukan tarif yang harus dibayar oleh konsumen. Fungsi pemerintah hanya sebagai pengatur perusahaan swasta dalam memberikan pelayanan publik. Sedangkan masyarakat berperan sebagai konsumen dan membayar secara langsung kepada perusahaan swasta.

$\checkmark$ Voluntary Service, pada sistem ini lembaga/organisasi swadaya secara sukarela memberikan pelayanan yang dibutuhkan oleh masyarakat. Mereka bertindak sebagai pengatur (service arranger) dan penyedia / produsen pelayanan (service producer).

$\checkmark$ Self Service, merupakan jenis / model pelayanan yang disediakan / dilakukan sendiri oleh individu / masyarakat.

\section{PEMBAHASAN}

\section{Sekilas Profil Kampung Wisata 3G (Glintung Go Green)}

Populasi yang padat di perkotaan mengakibatkan kebutuhan akan rumah semakin besar, termasuk di wilayah Kelurahan Purwantoro. Pembangunan perumahan untuk pemukiman warga di kawasan Kelurahan Purwantoro semakin pesat, sehingga lahan tanah pertanian semakin sempit. Diawali dengan pembangunan perumahan PUSKOPAD pada tahun 1986, kemudian pembangunan Perumahan Bhumi Purwantoro Agung tahun 1989 dan perumahan-perumahan lainnya. Hingga pada tahun 2000an, Kelurahan Purwantoro menjadi kelurahan yang padat penduduknya. Padatnya penduduk mengakibatkan ruang terbuka hijau semakin tidak ada, serta polusi udara yang kian menyengat. Hal ini menginspirasi warga di lingkungan Glintung, khususnya RW 23 untuk membuat inovasi berupa penghijauan pada kampung mereka. Ir. Bambang Irianto disebut sebagai sosok inspirator pertama yang memulai program penghijauan di desa Glintung.

Mayoritas penduduk kampung Glintung bermata pencaharian sebagai pengusaha kecil menengah, karyawan swasta, buruh, adapun PNS sangat sedikit sekali, sehingga income per kapita juga cukup rendah. Kampung Glintung ini awalnya terkenal sebagai kampung yang memiliki langganan 
Vol.05, No.01, April 2019

Doi: $10.24198 /$ cosmogov.v2i2.xxxxx

banjir setiap tahun dan kesehatan masyarakat yang memprihatinkan. Kemudian, Ir. Bambang Irianto secara gigih mengajak masyarakat di RW. nya untuk berswadaya mengembangkan kampung Glintung dengan konsep hijau. Singkat cerita, pastisipasi warga sekitar pun menjadi masif, mengingat situasi alam yang masyarakat alami.

Berangkat dari penanganan banjir yang hanya melalui perbaikan saluran air dengan hasil yang tidak memuaskan, kampung Glintung ini mendapat bimbingan dari Universitas Brawijaya dengan tidak lagi berfokus pada memperbaiki saluran, tetapi dengan inovasi berupa menabung air. Teknisnya air hujan di tampung di sumur biopori atau sumur resapan. Pada gilirannya langkah ini kemudian menjadi gerakan masyarakat, dengan sebutan gerakan menabung air (Gemar). Selama 3 tahun berlangsung langkah ini berdampak positif dengan bukti sumur warga rata-rata naik hingga 2 meter, saat musim hujan dampak banjir telah terkurangi, dan pada saat musim kemarau kesejukan dan kelembaban udara terjaga dengan baik. Program-program yang dikembangkan pada kampung wisata 3G (Glintung Go Green) adalah sebagai berikut :

1. Membuat 6 unit sumur injeksi/resapan yang dapat menampung 30.000 liter air.

2. Pembuatan biopori yang dapat menampung 5000 liter lebih air.

3. Parit resapan yang efektif dalam mengalirkan air hujan.
Dengan 3 program ini saja Kampung wisata Glintung Go Green dapat menyerap air sekitar 50.000 liter, sehingga ancaman banjir dapat teratasi dengan mudah. Saat ini warga sekitar mengklaim bahwa suhu udara di kampung tersebut layaknya suhu udara yang pernah mereka rasakan saat tahun 1970an dahulu.

4. Mendesain perkampungan menjadi kampung wisata $G o$ Green, sebuah kampung yang penuh dengan penghijauan, dimana pada setiap rumah diwajibkan menanam bunga atau pepohonan yang ditata sedemikian rupa dan semenarik mungkin.

5. Suku Dalu, berupa kerja bakti yang dilakukan warga saat malam hari. Program suku dalu ini juga sekaligus menjadi wahana tambahan dalam kampung wisata selain wahanawahana hijau yang telah ada.

6. Green Business, dengan pembentukan Green-koperasi yang dapat dimanfaatkan warga sekitar dalam mengembangkan usaha-usahanya.

Praktek layanan yang diciptakan oleh warga sekitar kampung wisata $3 \mathrm{G}$ (Glintung Go Green) untuk para wisatawan sebagai berikut:

1. Homestay di rumah warga. Bagi para wisatawan yang ingin menginap, warga kampung Glintung telah menyediakan homestay yang 
Vol.05, No.01, April 2019

Doi: $10.24198 / \operatorname{cosmogov.v2i2.xxxxx}$

dapat mereka manfaatkan selama berada di kampung tersebut. Layanan ini muncul atas inisiasi dari warga sendiri. Kamar dengan standar President Suite seharga 250 ribu perhari. Kamar level ini telah memiliki fasilitas kamar mandi dalam, televisi dan AC. Untuk level kamar sedikit lebih bawah para wisatawan dapat memilih kelas Superior dengan harga 150 ribu. Dan untuk level paling bawah warga menyediakan kelas ekonomi dengan harga 50 ribu.

\section{Edu-Green}

Layanan oleh warga kampung wisata Glintung ini diberikan kepada para wisatawan yang ingin belajar banyak tentang bagaimana mengelola dan merawat tanaman, hingga sampai cara mengelola program Go Green tersebut. Seluruh warga Glintung terlibat dalam praktek pelayanan ini. Wisatawan dapat belajar dan langsung praktek di lokasi, sebuah model pembelajaran yang sangat efektif pada zaman modern ini.

3. Layanan pembinaan kampung wisata $3 \mathrm{G}$

Layanan pembinaan kampung wisata 3G (Glintung Go Green) ini tidak hanya pada kawasan Malang saja, tetapi sudah lintas provinsi. Beberapa aparat desa dari luar provinsi sengaja datang untuk belajar dan meminta agar dibina oleh warga Glintung agar program kampung wisata hijau ini dapat mereka duplikasi di daerahnya masing-masing.

4. Layanan ojek keliling kampung wisata $3 \mathrm{G}$

Inisiatif ini diambil oleh warga sendiri dengan tujuan agar wisatawan mendapatkan kemudahan dalam menelusuri sudut-sudut kampung wisata tersebut.

\section{Sikap Pemerintah Daerah}

Saat awal konsep kampung wisata ini dikembangkan oleh warga, pemerintah daerah belum terlihat tertarik, belum ada tanda-tanda untuk turut ambil peran dalam program yang dicanangkan warga tersebut. Saat ini ketika program kampung wisata $3 \mathrm{G}$ ini menjadi fenomenal, pemerintah daerah Kota Malang menjadi turut ambil bagian, diantaranya dengan mengutus beberapa dinas yang ada, terutama Dinas Pertanian, Dinas Kebersihan dan Dinas Pertamanan untuk memberikan penyuluhan ke warga sekitar kampung Glintung. Namun yang menarik adalah, warga sekitar menganggap bantuan dari pemerintah daerah tersebut hanyalah sebagai stimulan saja. Anggapan (sebagai stimulan) ini mereka nilai begitu penting mengingat spirit gotong royong dan swadaya yang telah mereka rumuskan sejak awal masih begitu penting untuk dipertahankan.

Kerjasama yang telah terbangun antara pemerintah daerah dengan warga kampung wisata 3G masih seputar penyuluhan saja, lebih dari itu tampaknya belum pernah dilakukan. Kerjasama-kerjasama yang lebih strategis, semisal dalam hal pelayanan publik, belum terancang dengan baik. Belum ada sentuhan kerjasama antara pemerintah daerah dan warga sekitar mengakibatkan barang yang diproduksi warga berupa layanan kepada wisatawan masih terkesan biasa-biasa 
Vol.05, No.01, April 2019

Doi: $10.24198 /$ cosmogov.v2i2.xxxxx

saja. Tampaknya ke depan perlu untuk dirumuskan secara bersama-sama antara pihak warga dan pihak pemerintah daerah terkait produk layanan berbasis citizen tersebut.

\section{Coproduction Sebagai Solusi atas Perbaruan Layanan Oleh Warga}

Era citizen / community welfare merubah paradigma pelayanan dari birokrasi yang semula "dilayani", menjadi birokrasi yang "melayani". Fungsi pelayanan yang melekat pada birokrasi, tidak serta merta menempatkan warga masyarakat sebagai kelompok pasif. Partisipasi masyarakat dalam pelayanan, idealnya harus ditingkatkan, karena sejalan dengan misi pemberdayaan yang harus lebih diutamakan (empowering rather than serving). Pemberdayaan ini akan menuntun pada hadirnya peningkatan partisipasi warga masyarakat dalam pelayanan publik.

Partisipasi masyarakat dalam pelayanan publik dikenal dengan konsep Coproduction. Konsep ini dikenal pertama kali dan dikembangkan sejak tahun 1980-an, ketika pakar administrasi publik dan politik urban membangun teori yang menjelaskan kegiatan kolektif dan peran kritis dari keterlibatan warga masyarakat dalam penyediaan pelayanan barang dan jasa. Teori co-production dalam pemberian layanan yang baik adalah sebuah penataan maupun proses pemerintah dan masyarakat membagi tanggung jawab (conjoint responsibility) dalam menyediakan pelayanan publik. Sehingga kita tidak lagi membedakan warga masyarakat sebagai pelanggan tradisional dengan pemerintah sebagai penyedia layanan. Kedua pihak dapat bertindak sebagai bagian dari pemberi layanan.

Teori coproduction dalam pelayanan publik dapat dipahami dengan melalui konsep-konsep pelanggan dan produksi di sektor publik, yaitu consumer produser, regular producer dan co-production. Menurut Parks, consumer producers adalah pihak yang berhubungan dengan produksi yang pada akhirnya akan mengkonsumsi akhir dari produk yang dibuatnya. Regular producers adalah pihak yang menyelenggarakan proses produksi, yang akan merubah output menjadi pembayaran, yang pada akhirnya akan membelanjakannya untuk barang dan jasa lainnya. Dalam hal ini co-production memerlukan kedua pihak berkontribusi input pada proses produksi untuk barang dan jasa tertentu. Dengan kata lain, dalam banyak pelayanan, proses produksi output dan outcome memerlukan partisipasi aktif dari penerima layanan barang dan jasa (Parks, 1981).

Menurut Cooper, sebagaimana dikutip oleh McLaverty (2002: 15), menjelaskan bahwa partisipasi publik (terutama dalam proses pengambilan keputusan) adalah sarana untuk memenuhi hak dasar sebagai warga. Pada akhirnya tujuan dari partisipasi publik adalah untuk mendidik dan memberdayakan warga. Sedangkan menurut Marschall (2004: 231), tujuan dari partisipasi publik adalah pada 
Vol.05, No.01, April 2019

Doi: $10.24198 /$ cosmogov.v2i2.xxxxx

dasarnya untuk mengkomunikasikan dan mempengaruhi proses pengambilan keputusan sebagaimana juga membantu dalam pelaksanaan pelayanan.

Heller menjelaskan dua bentuk dasar partisipasi, yaitu partisipasi akar rumput (grass-root participation) yang mengacu pada organisasi dan gerakan sosial yang didasarkan pada inisiatif warga yang memilih tujuan dan metode mereka sendiri, dan partisipasi mandat pemerintah (government-mandated participation) yang melibatkan persyaratan hukum di mana akan ada kesempatan bagi masukan warga terhadap pengambilan keputusan (kebijakan) atau pelaksanaan sebuah lembaga.

Secara sederhana, Cooper membedakan partisipasi ke dalam partisipasi tidak langsung (indirect participation) dan partisipasi langsung (direct participation). Partisipasi tidak langsung, misalnya, partisipasi dalam hal penyelenggaraan negara dengan memilih wakilnya untuk duduk di kursi parlemen, sama halnya ketika menyuarakan pendapat melalui media massa untuk perbaikan pelayanan publik oleh pemerintah. Sementara partisipasi langsung bisa berupa keterlibatan secara langsung warga dalam penyelenggaraan pemerintahan, seperti menjadi komisi penasihat, aktivitas dengar pendapat, keterlibatan di kelompok-kelompok kepentingan dan partisipasi dalam lembaga pemerintah yang menyelenggarakan kegiatan pemberian pelayanan umum.
Penyelenggaraan pelayanan umum haruslah mendapat dukungan partisipasi dari masyarakat. Konsep partisipasi masyarakat terhadap fungsi pelayanan yang dilakukan oleh pemerintah, dapat berupa taat terhadap peraturan pemerintah, membangun kesadaran hukum, kepedulian terhadap peraturan yang berlaku, dan dapat juga berupa dukungan nyata dengan membantu secara langsung proses penyelenggaraan pelayanan umum. Dalam konsep Coproduction misalnya, Coproduser adalah warga atau sebagian dari warga masyarakat yang terlibat dalam penyelenggaraan pemberian layanan umum, sebagai bentuk partisipasi. Ini berangkat dari konsep Coproduction yang dijelaskan oleh Ostrom. Dalam definisinya Ostrom (1996: 86) menjelaskan bahwa "coproduction as the process through which inputs used to produce a good or service are contributed by individuals who are not "in" the same organization", yaitu bahwa coproduction adalah proses di mana input yang digunakan untuk menghasilkan barang atau jasa diberikan oleh individu yang bukan berasal dari organisasi yang sama. Keterlibatan warga dalam produksi layanan (yang seharusnya dilakukan oleh pemerintah) adalah termasuk kegiatan coproduction dalam pelayanan publik.

Untuk memaksimalkan potensi kampung wisata 3G (Glintung Go Green), perlu diterapkan model kerjasama coproduction antara pemerintah daerah dalam hak ini Kota 
Vol.05, No.01, April 2019

Doi: $10.24198 /$ cosmogov.v2i2.xxxxx

Malang dengan warga desa Glintung. Kreativitas yang dimiliki oleh warga setempat begitu bernilai dan masih sangat berpotensi untuk lebih dikembangkan lagi. Kerjasama dengan pemerintah daerah dapat menambal beberapa kekurangan yang ada pada ranah layanan publik yang diberikan oleh warga kepada wisatawan. Bagaimanapun wisatawan yang datang ke kampung wisata tersebut tentu berkeinginan memperoleh layanan yang baik dan bahkan berstandar tertentu. Dengan adanya conjoint antar kedua belah pihak, niscaya akan terwujud sebuah standar pelayanan yang lebih baik lagi dan sesuai dengan keinginan para wisatawan yang berkunjung ke lokasi wisata.

Pentingnya peran aktif kedua belah pihak dalam menyelenggarakan pelayanan publik dapat dijelaskan dalam konteks partisipasi. Partisipasi publik berhubungan erat dengan kedua belah pihak; pemerintah dan warga (citizen). Melalui sisi pemerintah, kita bisa melihat penerapan kebijakan dan penggunaan teknik-teknik manajemen dalam pemberian pelayanan kepada masyarakat (wisatawan) sekaligus dalam rangka penegakan peraturan, sedangkan pada sisi masyarakat adalah keterlibatan dalam berdisiplin dan menaati aturan, serta dukungan langsung dalam proses pemberian pelayanan publik. Pada tahap ini, pemerintah bisa saja membuat semacam aturan (regulasi) untuk melindungi area wisata ini agar tetap terjaga kelestariannya. Pemerintah dapat mengambil peran sebagai sebagai pengatur (arranger). Implementasinya dapat berupa mengatur atau membuat regulasi tertentu yang memberikan fasilitas bagi berkembangnya peran dan fungsi aktor-aktor non publik dalam menyediakan layanan (Savas: 2000). Regulasi yang paling tepat dan mendesak tentu adalah perlindungan atas kawasan ini agar tetap terjaga kelestariannya. Kawasan ini harus tetap terjaga dan tidak boleh tersentuh oleh proyek-proyek industrialisasi yang seringkali tidak ramah lingkungan. Selain itu, pemerintah daerah juga perlu bekerjasama dengan warga kampung Glintung dalam menduplikasi format kampung wisata 3G ini ke desa-desa lainnya, dengan tujuan agar Malang yang dahulu terkenal dengan udara sejuk dan dinginnya dapat kembali seperti sedia kala.

Selain sebagai pengatur (arranger), pemerintah daerah juga dapat mengambil peran sebagai partner, berkolaborasi dengan masyarakat dalam produksi layanan (cooperation and cooproduction). Sebagai partner, pemerintah dapat melakukan kerjasama yang baik dengan warga kampung Glintung yang memberikan layanan kepada wisatawan yang berkunjung. Warga desa Glintung telah memiliki beberapa layanan tradisonal seperti homestay, ojek keliling kampung, edugreen, dan pembinaan kampung wisata. Beragam layanan yang telah ada ini dapat ditingkatkan dan dikembangkan kualitas pelayanannya, jika dilakukan 
Vol.05, No.01, April 2019

Doi: $10.24198 / \operatorname{cosmogov.v2i2.xxxxx}$

kerjasama yang baik dengan pemerintah.

Praktek model Coproduction pada kawasan kampung wisata 3G (Glintung Go Green) tentu akan memberikan warna baru pada berbagai layanan yang telah ada, misalnya:

1. Homestay di rumah warga.

Kerjasama antara pemerintah daerah dengan warga idealnya akan menambah kualitas dari pelayanan homestay ini. Dari segi fasilitas kamar misalnya, saat terjadi kerjasama maka kelengkapan fasilitas hendaknya dapat lebih terpenuhi. Kelengkapan fasilitas tidak hanya untuk kamar kelas atas saja, kelas menengah dan bawah juga harus lebih diperhatikan. Meski layanan ini muncul atas inisiasi dari warga sendiri, akan tetapi bekerja sama dengan pemerintah bukanlah hal yang salah, selama saling menguntungkan antar kedua belah pihak.

\section{Edu-Green}

Layanan oleh warga kampung wisata Glintung ini diberikan kepada para wisatawan yang ingin belajar banyak tentang bagaimana mengelola dan merawat tanaman, hingga sampai cara mengelola program go green tersebut. Keterlibatan pemerintah daerah bisa dengan menyediakan para ahli tanaman agar edukasi perihal tanaman dapat lebih komprehensif lagi. Tentu, para ahli tanaman tersebut pihak pemerintah dapat mengambil tenaga-tenaga ahli dari berbagai perguruan tinggi yang ada di Kota Malang. Para tenaga ahli tersebut harus mentranfer pengetahuannya kepada warga dan wisatawan yang berkunjung. Seluruh warga Glintung tetap terlibat dalam praktek pelayanan ini.

3. Layanan pembinaan kampung wisata $3 \mathrm{G}$

Karena peminat yang berkeinginan untuk belajar semakin banyak, maka kerjasama antara pemerintah dengan warga setempat perlu segera dilakukan. Layanan pembinaan oleh warga Glintung kepada para peminat dari berbagai daerah ini perlu mendapat support oleh pihak pemerintah. Adapun support yang mungkin dapat dikembangkan adalah penyediaan perangkat teknologi yang mumpuni agar proses pembelajaran antara warga setempat dengan para peminat dari berbagai daerah ini dapat berlangsung dengan lebih efektif dan efisien lagi. Coproduction yang dikembangkan berdasarkan asas saling memberikan keuntungan.

4. Layanan ojek keliling kampung wisata $3 \mathrm{G}$

Inisiatif ini memang berawal dari warga sendiri. Mereka bertujuan agar wisatawan mendapatkan kemudahan dalam menelusuri sudut-sudut kampung wisata tersebut. Namun dengan fasilitas sepeda motor yang ada, nampaknya agak berbanding terbalik dengan tujuan awal keberadaan kampung wisata go green yang pro terhadap penghijauan dan anti terhadap pencemaran udara. Dengan model Coproduction pemerintah dapat menjalin kerjasama dengan warga sekitar melalui penyediaan alat transportasi yang ramah lingkungan. 
Vol.05, No.01, April 2019

Doi: $10.24198 /$ cosmogov.v2i2.xxxxx

Alat transportasi ramah lingkungan ini dapat disediakan oleh pihak pemerintah dengan sistem kerjasama yang saling menguntungkan. Pihak warga akan diuntungkan dengan tetap terjaganya penghijauan di kampung mereka, sambil menambah satu keunikan wahana wisatanya dengan alat transportasi ramah lingkungan. Sementara pemerintah daerah juga mendapat keuntungan bertambahnya destinasi wisata di daerahnya.

\section{KESIMPULAN}

Pada era citizen/community welfare ini, porsi yang cukup besar harus diberikan kepada warga negara sebagai pemberi layanan dalam masyarakat. Pada kampung wisata ini pula, negara/pemerintah dapat melakukan empowering terhadap masyarakat. Dalam melaksanakan empowering ini, pemerintah dapat melakukan penguatan melalui transfer knowledge/pengetahuan, kemampuan dan ketrampilan terhadap warga setempat. Selain itu pemerintah juga dapat memberikan posisi, peran, wewenang, lisensi (perijinan) kepada warga bila dibutuhkan. Selain peran empowering, pemerintah menurut Leach, Stewart dan Walsh (1994) juga dapat berperan enabling, berupa peran indirect service dengan mendorong dan meningkatkan kemampuankemampuan yang telah dimiliki oleh warga kampung wisata $3 \mathrm{G}$ sehingga mereka dapat memenuhi kebutuhan layanan mereka sendiri (community oriented enabler).
Pemerintah dapat mengambil peran dengan meningkatkan teknikteknik manajerial dalam pemberian pelayanan kepada warga, ini dilakukan dengan cara menyiapkan dan memanfaatkan seluruh sumber daya organisasi yang dimiliki untuk mencapai tujuan. Sedangkan peran pada sisi masyarakat adalah partisipasi aktif baik dalam hal ketaatan, maupun dukungan langsung dalam proses penyelenggaraan pelayanan publik. Melalui kerjasama model Coproduction ini, diharapkan ke depan dapat memberikan nilai tambah pada warga kampung wisata 3G (Glintung Go Green). Nilai tambah tersebut dapat berupa kesejahteraan masyarakat yang makin meningkat, kesehatan yang semakin membaik, pendidikan yang lebih layak dan lain-lain. Sehingga, pada periode-periode berikutnya, format kampung wisata ini dapat lebih berfokus pada pendapatan masyarakat lokal.

\section{DAFTAR PUSTAKA}

Bovaird, Tony \& Elke Loffler. (2009). Public Management and Governance. Taylor \& Francis Group. London \& New York.

Denhardt, Janet \& Robert Denhardt. (2003). The New Public Service, Serving Rather than Steering. Armonk. New York.

King, Cheryl Simrell, Camilla Stivers. (1998). Government is us: Public Administration in an AntiGovernment Era. Sage Publications. London 
Vol.05, No.01, April 2019

Doi: $10.24198 /$ cosmogov.v2i2.xxxxx

Leach, Steve \& John Stewart, Kieron Walsh. (1995). The Changing Organization and Management of Local Government, Government beyond the Centre Series. London: MacMillan Press.

McLaverty, Peter. (2002). Public

Participation and Innovations in Community Governance. University of Michigan. Ashgate. Michigan.

Naisbitt, John. (1982). Megatrends. Warner Books. New York.

Savas, Emanuel S. (2000). Privatization and Public-Private Partnerships. Chatham House. New York.

\section{JURNAL}

Heller, Patrick. (2001). Moving the State: The Politics of Democratic Decentralization in Kerala, South Africa and Porto Alegre. Politics and Society.

Parks, Roger B, et al. (1981). Consumers as Coproducers of Public Services: Some Economics and Institusional Considerations. Indiana University and University of South Carolina.

Kiser, Larry L. \& Stephen L Percy. (1980). The Concept of Coproduction and Its Implication for Public Service Delivery. Paper presented at the 1980 Annual Meetings of the American Society for Public Administration, on April 13-16. Indiana University. Bloomington.
Marschall, Melissa J. (2004). Citizen Participation and the Neighborhood Context: A New Look at the Coproduction of Local Public Goods. Political Research Quarterly. Academic Research Library.

Ostrom, Elinor. (1996). Crossing the Great Divide: Coproduction, Synergy, and Development. World Development, Vol. 24, No. 6 (June 1996), 1073-87. 